\title{
Internal Capital Markets And Equity Restructuring
}

Anwar Boumosleh, Lebanese American University, Lebanon Abdallah Dah, Lebanese American University, Lebanon Mustafa Dah, Lebanese American University, Lebanon

\begin{abstract}
Inefficient internal capital market is often blamed for conglomerate diversification discount. While the positive market reaction to spin-off announcements is in conformity with that claim, the abnormal market return on tracking stock announcements is certainly not. This paper investigates the possibility of a bright side for internal capital markets in conglomerates that track business units as a mean of equity restructuring. This paper finds no evidence of a diversification discount for firms with a tracking stock. Partial support on the presence of diversification discount is found for a pair-matched sample of spin-off firms. This paper also finds evidence on more efficient internal capital markets for the sample of tracking-stock firms. The results may suggest that the conglomerates' choice between tracking business units or spin-off of business units depends on the efficient allocation of internally generated funds.
\end{abstract}

Keywords: Diversification Discount; Spinoffs; Tracking Stocks; Internal Capital Markets

\section{INTRODUCTION}

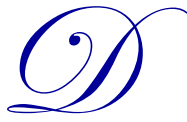

iversification gained popularity in the late 1950's \& 1960's, stabilized in the 1970's, and lost ground to more focused firms since the 1980's. Berger \& Ofek (1995), find diversified firms sell at a discount compared to stand alone firms. Shin \& Stulz (1998) examine the performance of internal capital markets in diversified firms and conclude that diversified firms have inactive and inefficient internal capital markets. Billet \& Mauer (2000) explain the role of internal capital markets in the market's positive reaction to tracking stocks announcements.

In addition to conglomerates that opt for tracking segments as a mean of capital restructuring (referred here thereafter as tracking-stock firms), this paper examines the performance of the internal capital markets for two other groups of diversified firms; specifically, a matched sample of conglomerates that opt for the spin-off option (referred here thereafter as spin-off firms), and a matched sample of diversified firms that didn't opt for capital restructuring (referred here thereafter as diversified firms). Following the methodology presented by Berger and Ofek (1995), this research examines the presence of a diversification discount for spin-off and tracking conglomerates. The results show that tracking stock firms have the highest excess value (lowest diversification discount), while spinoff firms have the highest diversification discount among all three firm categories.

This paper also investigates how efficient are internal capital markets in allocating the firm's resources. If the efficient internal capital market is a factor behind the choice of the tracking stock alternative as opposed to other means of restructuring, one would expect a different and less valued role for internal capital markets in spin-off firms, as well as, diversified firms. The regression results indicate a more active and efficient role for internal capital markets in the tracking-stock sample. The internal capital market for this group of conglomerates shows that firms seem to pay more attention to their segments' performance in absolute and relative terms. That is, the segment's capital spending is sensitive to its own cash flow, as well as, to the firm's other cash flows. On the other hand, segment's investment for the other two groups of firms, diversified and spin-offs, showed higher sensitivity for owns segments cash flow and much lower dependence on other segments cash flows. Furthermore, the internal capital markets for tracking firms seem to pay more attention to the segment's performance and investment opportunities as compared to diversified and spin-off firms. 
The paper contributes to the existing literature in three respects. First, it highlights the importance of internal capital markets in the capitalization process supporting the pecking order hypothesis presented in Myers (1986). Second, the paper provides further evidence that the diversification discount exists as a result of management behavior. In essence, it commonly suggested in the literature that agency problems (rent seeking behavior of segment managers (Sharfstein and Stein, 2001) and socialism in internal allocation of funds (Rajan et al., 2000) give rise to the diversification discount. Our results suggest that managers have great discretion in mitigating the diversification problem by their choice of capital restructuring or promoting transparency. Third, our paper shows the importance of the external capital market in disciplining management through their effect on the value of the firm. Basically, the results suggest that by tracking one segment of the firm outside investors might either indicate management's behavior in managing the other segments or indeed becoming more interested to effectively monitor the whole firm rather than just the segment and subsequently reward or punish the stock price of the conglomerate.

Section II reviews the literature on diversified, spin-offs, and tracking stock firms. Section III presents the sample design and methodology. Section IV presents descriptive statistics. Section V provides findings on the diversification discount (premium) for conglomerate firms included in the sample. Section VI presents empirical findings on the efficiency of internal capital markets for all three firm categories, and section VII concludes.

\section{LITERATURE REVIEW AND HYPOTHESES DEVELOPMENT}

\section{A- $\quad$ Literature Review}

Separation of ownership and control give rise to agency costs that appear in several forms (e.g. Yermack, 2006; Morck, Schleifer and Vishny, 1990). In this vein, Aggarwal and Samwick (2005) argue that corporate diversification is a form of agency cost. By diversifying into different lines of business, CEOs extract private benefits in the form of prestige, better employment opportunities, and generous benefits. Denis, Denis and Sarin (1997) and Berger and Ofek (1995) hypothesize and provide evidence that diversified firms sell at a discount to focused firms. In their argument Berger and Ofek (1995) blame cross subsidization for the discount. Lately, Scharfstein and Stein (2000) and Rajan, Servaes, and Zingales (2000) present theoretical arguments of the existence of a diversification discount due to the misallocation of internally generated funds. In an original approach, Shin \& Stulz (1998) examine the sensitivity of one segment investments to the cash flows of other segments in the firm. They find that investment by segments in diversified firms depend more on their own cash flow than on the firm's cash flow. Additionally, segment investments are insensitive to other segments investment opportunities. They conclude some inefficiency exists in the internal capital markets.

Counter arguments on the diversification discount focus mainly on the methodology used in empirical tests. Campa and Kedia (2002) argue that conglomerate firms' values were low before becoming diversified. Graham et al (2002) show that the discount attached to diversified firms resulted from acquisitions of business segments that were already trading at a discount. Villalonga (2004), using business information tracking services (BITS) data, find that the discount attached to conglomerate firms is an artifact of the Compustat segment data.

Supporting evidence on the existence of a diversification discount and inefficiency of the internal capital market is provided in the literature on spin-offs. Spin-off is a corporate decision where shareholders receive pro-rata stock distribution and spin-off units gain independent management. The main phenomenon of spin-offs is that these business units lose their privilege of using, when needed, funds produced from the other business units in the firm. The advantage, however, is that these units operate as focused independent firms. Indeed, spin-off announcements have been accompanied, in general, with positive abnormal returns. This positive market reaction is interpreted by some a result of the investor's preference to more focused firms, and by others a result of a lower magnitude of agency cost, and the elimination of cross-subsidization between different divisions of conglomerate firms. Veld and Merkoulova (2009) examine the abnormal returns for 26 spin-off announcements and find an average of 3.02 percent of abnormal returns. Chemmanur \& Yan (2004) report better long-run performance for spin-offs of divisions that are in different lines of business than the parent firm. Finally, Chemmanur and Paeglis (2001) compare abnormal returns on announcements of spin-offs, tracking-stocks, and carve-outs. While research findings reported similar positive markets reactions on announcements of spin-offs and tracking stocks, a better long-run performance 
for spin-offs compared to tracking stocks and carve-outs was found. Obvious in the literature on spin-offs is that the benefits obtained from increasing focus and independence exceed the costs associated with losing the use internal capital market.

Another related area of debate focuses on the conglomerates choice of tracking stocks as a form of capital restructuring. Professor Greenwald of Colombia sees it as a form of financial engineering with no effect on the firm's value (New York Times, July 12, 1994). However, there is increasing evidence on the value improving role of tracking stocks.

A tracking or targeted stock represents the shareholders interest in the performance of a specific segment in a conglomerate firm. Unlike spinoffs, or equity crave outs, a tracking stock preserves the value of the internal capital market and keeps the tracked section under the umbrella of the parent company. Financial reporting, earnings per share, dividends, and managerial incentives could be designed separately for the tracked section allowing more transparency for outside investors about managing the tracked segment and generally managing the whole firm. However, ownership of assets and liabilities remain consolidated within parent firm $^{1}$. Danielova (2008), using a logistic regression model, finds that an efficient internal capital market increases the probability of tracking-stock option as a mean of capital restructuring, and documents more favorable market reactions to unanticipated announcements of tracking stocks. D'Souza \& Jacob (2000) examine the market reaction to targeted stock announcements. They find that the tracking stock, as a restructuring option is value enhancing and their performance remains more correlated to the parent firm's performance. Billet \& Mauer (2000) argue that the positive market reaction to targeted stock announcement is as strong as that of spinoffs, for the period 1980-1997. The abnormal returns to the announcements of tracking stocks are attributed to the good performance of the firm's internal capital markets. Billet and Mauer (2000), also, argue that firms that issued targeted stocks traded at a premium compared to their peers of diversified firms with comparable number of business segments. In summary, the adoption of tracking stocks seems to arise from the need for capital restructuring. Mainly, tracking stocks improve transparency and preserves the internal capital market; two phenomena are received positively by the market.

\section{B- Hypotheses Development}

Tracking stocks represent a natural phenomenon to examine the importance of the internal capital market. First, unlike spin-offs tracking stocks remain part of the whole firm and thus are eligible to use funds that are generated by any of the segments in the firm. Based on that, it is safe to say that if internally generated funds are efficiently allocated then this will be a motive for firms to adopt the targeted stock option. Therefore, we hypothesize:

H1: Firms restructuring through tracking stock possess more efficient internal capital markets than firms spinning off one business segment.

Second, adoption of tracking stock by the firm is perceived as a signal about the efficiency of the internal capital market. Similarly, spin-offs are received from the market as a signal of more focus and elimination of inefficient cross subsidy. Accordingly, we argue that not only do tracking stock firms increase focus shareholders interest on a segment but also increase shareholders' awareness about the whole firm. Indeed, it is necessary for those firms that the market be able to observe the advantage that tracking stock firms have in terms of efficient internal capital markets. Thus, it is expected that the adoption of tracking stock have lower diversification discount prior to the adoption of tracking stock. In addition, post the adoption the value of the whole firm is improved and reflected in even lower diversification discount. Thus, we state the hypothesis in the alternative form:

H2a: Firms adopting the tracking stock option enjoy lower diversification discount than spin-off firms.

H2b: Firms with tracking stocks enjoy even lower diversification discount after the adoption.

\footnotetext{
${ }^{1}$ Since the profits of one division may be offset by the losses of another one, this form of capital restructuring allows the firm to benefit from tax reductions. Moreover, Stock tracking is a tax free option since there is no legal division of the firm's assets.
} 
Third, by comparing tracking stock firms to spin-off firms and the population of diversified firms, our empirical approach is robust to the measures of diversification discounts used. In other words, Villalonga's argument that the diversification discount is an artifact of Compustat database is no longer a concern. Thus, we compare our tracking stock firms to the population of diversified firms and expect:

H3a: Firms restructuring through tracking stock possess more efficient internal capital markets than other diversified firms.

H3b: Firms adopting the tracking stock option enjoy lower diversification discount than other diversified firms.

\section{C- $\quad$ Empirical Approach}

The literature on targeted stocks emphasized market reaction to announcements of such equity restructuring forms. This approach is then extended to relate this abnormal change in equity prices to some value measure (proxies) of the internal capital market of conglomerate firms (Billet and Mauer 2002). However, for more concrete results, one needs to investigate closely the mechanism of how the company's cash flows are consolidated and dispersed by internal capital markets. This approach is used by Shin and Stulz (1998) to detect differences in investment behavior between segments of diversified firms and comparable stand-alone firms. This model is extended in this paper to compare how active and efficient internal capital markets are in the three different groups of diversified firms, prior to the restructuring announcement. Trying to estimate the responsiveness of segment investment to segment cash flow, other segments cash flow, and absolute and relative performance measures, will give better information about the working of the internal capital market in all three categories of diversified firms.

This paper tests, first, the presence or absence of a diversification discount for all three groups of conglomerates, prior to the restructuring dates of spin-offs and tracking-stocks, included in this research. If the internal capital markets are any better for firms who opt for tracking business units, one would expect such conglomerates to enjoy a lower diversification discount (higher premium) as compared to their peer matched samples of diversified and spin-off firms. Furthermore, this paper attempts to analyze the performance of internal capital markets prior to capital restructuring. For the internal capital market to be active and efficient, one expects segment's investment to be as sensitive to its own cash flow and other segments' cash flows. Furthermore, segment's investment should also be sensitive to segment's performance and investment opportunities.

\section{SAMPLE DESIGN AND METHODOLOGY}

\section{A- Data}

The list of spinoff firms and firms that issued tracking stocks was obtained from the Securities Data Company (SDC) Platinum database. Furthermore, additional information on tracking stock parent companies was obtained using Elder \& Westra (2000) paper.

Data on spinoffs and tracking stock firms was obtained from the Compustat Fundamentals Annual and Compustat Segments. The model used in this paper is mainly based on the segment data of the included firms. The Compustat Segments is used to obtain segment data on six variables: Capital Expenditures, Identifiable Total Assets, Depreciation \& Amortization, Net Sales, Operating Profit, and segment SIC codes.

In general, there are around fifty tracking stock announcements made. However, in this paper, Compustat data availability limits the number of tracking stock firms studied to only 19 firms. As for spinoff firms, the SDC database reports that 1495 spinoff announcements were made. However, in order to compare the efficiency of the internal capital market for spinoff firms and tracking stock firms, a matched sample of 19 spinoff firms with similar characteristics to tracking stock firms is used. Spinoff firms are matched to tracking stock firms based on three criteria. First, they are matched based on announcement data. The difference in announcement dates should not exceed 2 years. Second, the firms are matched based on 2-digit SIC codes. However, in some cases, it is not possible to match on 2-digit SIC codes. As a result, a 1-digit SIC code matching is implemented. Finally, matching is performed based on the firm's size. That is, the book value of Assets for the spinoff firm is required to be within 
$70 \%-130 \%$ of the tracking stock firm book value of assets. If no firms were found within this filter, the spinoff firm with the closest size is used. Moreover, a matched sample of 19 diversified firms with similar characteristics to tracking stock firms is also used. Matching diversified firms to tracking stock firms was performed based on the same criteria used for the matched sample of spin-off firms.

As mentioned earlier the model used in this paper is based on segment information. Moreover, the model requires the computation of Tobin's Q for each segment. However, since the market value for each segment is not available, the median Tobin's $\mathrm{Q}$ for single segment firms with the same 2-digit SIC code is used to proxy for a given segment's Tobin's Q. Each year, single segment firms are identified as those firms which are included in the Compustat Fundamentals annual but not included in the Compustat segments. The Tobin's Q for single segment firms is computed following Chung and Pruitt (1994) measure.

\section{B- Methodology}

To investigate whether or not difference in diversification discount (or premium) exists between the three categories of diversified firms, section $\mathrm{V}$ calculates the imputed values of different business segments within the conglomerates as if they were stand-alone firms. The sum of the imputed values compromise the imputed value for the diversified firm and, thus, it is compared to its market value to see whether diversification enhances or destroys shareholders' wealth. In doing so, I follow the methodology developed by Berger and Ofek (1995). Different industry multiples (sales, assets and earnings) are used to estimate the imputed values of the firm's individual segments.

Section IV studies how efficient internal capital markets are for firms who opt for capital restructuring. In that sense, I will adopt the definition of efficient internal capital markets used by Shin and Stulz (1998). That is, the segments' investment should show, more or less, the same sensitivity to segment's cash flow, as well as to other segment's cash flow. It is expected that such an argument will hold more for firms who opt for the tracking stock option. Furthermore, efficient internal capital markets also suggest that the segment's investment should be sensitive to its performance relative to other segments within the firm. Allowing for segment specific fixed effects, the model used investigates the relationship between the segment's capital expenditure, as dependent variable, and a number of explanatory variables that include the segment's own cash flow, other segments' cash flows, sales ratio, segment's Tobin's Q. A vector of time dummy variables is also included to account for different economic conditions over the period. This is done for the three samples mentioned earlier. Shin and Stulz (1998), using a sample of segments' of diversified firms, found that an increase in segment own cash flow has much more impact than an increase in other segments' cash flows on segment investment. This argument was used as evidence on inactive and inefficient capital markets for diversified firms. If the internal capital market is to be credited for the positive market reaction on announcements of tracking stocks, one would expect the segment's investment for such firms to be more sensitive to other segments cash flow than firms who opt for spin-offs, as a mean of capital restructuring. Moreover, segment cash flow should be sensitive to the segment's performance in absolute and relative terms. That is, the firm's resources should be directed towards better performers with high investment opportunities.

\section{C- Descriptive Statistics}

Table (1) provides some descriptive statistics at the segment level in all three types of firms. Information on segment investment opportunities, proxied by segment's Tobin "Q" shows better investment opportunities for segments of spin-off firms compared to their peer-matched of tracking-stock and diversified firms. On the other hand, segment cash flow and earnings before interest and tax normalized by segment's assets are higher on average for diversified firms. Tracking-stock firms enjoy a better asset utilization ratio as compared to their counterparts of other firms. The mean sales-to-asset ratio is substantially higher for tracking-stock firms as compared to their counterparts of other firms. No clear trend can be detected on segments investment, measured by capital expenditure normalized by segment assets, or relative size of segment-to-firm asset for the three groups of firms. Differences exhibited by table (1) were clearly low and mostly insignificant due to the pair-matching approach followed in choosing firms for spin-offs and diversified firms. 
Table 1: Descriptive Statistics

\begin{tabular}{|l|c|c|c|c|c|c|}
\hline & \multicolumn{2}{|c|}{ Tracking-stock } & \multicolumn{2}{c|}{ Spin-offs } & \multicolumn{2}{c|}{ Diversified } \\
\cline { 2 - 7 } & Mean & Median & Mean & Median & Mean & Median \\
\hline Segment Tobin "Q" & 0.681 & 0.587 & 0.718 & 0.708 & 0.632 & 0.612 \\
\hline Segment-to- firm assets & 0.36 & 0.2 & 0.29 & 0.24 & 0.34 & 0.28 \\
\hline $\begin{array}{l}\text { Segment cash flow-to-segment } \\
\text { assets }\end{array}$ & 0.106 & 0.177 & 0.122 & 0.136 & 0.139 & 0.186 \\
\hline Segment sales-to-segment assets & 1.4 & 1.071 & 1.252 & 1.013 & 1.233 & 1.084 \\
\hline $\begin{array}{l}\text { Segment earnings (EBIT)-to- } \\
\text { segment asset }\end{array}$ & 0.057 & 0.101 & 0.087 & 0.095 & 0.085 & 0.113 \\
\hline $\begin{array}{l}\text { Segment capital expenditure-to- } \\
\text { segment assets }\end{array}$ & 0.056 & 0.051 & 0.053 & 0.057 & 0.069 & 0.049 \\
\hline
\end{tabular}

Table (2), shows the number and percentage of segment-year who has been a pure recipient of funds from the internal capital market or simply has positive excess capital expenditure. Excess capital expenditure is defined as segment's capital spending minus segment's cash flow. A segment is considered to be a net recipient of funds if the segment's capital expenditure exceeds its cash flow.

Table 2: Segment's Excess Capital Expenditure (EXCAPs)

\begin{tabular}{|l|c|c|c|c|c|c|}
\hline & \multicolumn{2}{|c|}{ Tracking } & \multicolumn{2}{c|}{ Spin-offs } & \multicolumn{2}{c|}{ Diversified } \\
\hline & $\begin{array}{c}\text { Number of } \\
\text { segments per year }\end{array}$ & $\%$ & $\begin{array}{c}\text { Number of } \\
\text { segments per year }\end{array}$ & $\%$ & $\begin{array}{c}\text { Number of } \\
\text { segments per year }\end{array}$ & $\%$ \\
\hline Positive EXCAP & 41 & 7.7 & 62 & 10.1 & 53 & 7.8 \\
\hline Negative EXCAP & 492 & 92.3 & 553 & 89.9 & 623 & 92.2 \\
\hline Total & 533 & & 615 & & 676 & \\
\hline
\end{tabular}

Table (2) also shows that 7.7 percent of the segment-year observations of tracking stock firms are subsidized by internal capital markets, since their capital expenditure exceeds the segment's cash flow. When compared to 10.1 percent for spin-off firms and 7.8 percent for diversified firms, no statistically significant difference is observed. Descriptive analysis suggests active internal capital markets for all three groups of firms. That said, active financial resource management, exercised by internal capital markets, could have either valueimproving or value-deteriorating effects. While active internal capital market is a necessary condition for any possible gains associated with economies of scale, the presence of cross-subsidies and "socialism" among different divisions could have serious adverse effects on shareholders' wealth. An active and value improving role to internal capital markets can only be achieved by investing the company's resources in projects and divisions that have the best investment opportunities.

\section{D- $\quad$ Findings on the Diversification Discount for Conglomerates}

Several studies have documented that diversification reduces the value of the firm. Comment \& Jarrell (1995) document an inverse relationship between different diversification measures and stock returns. Berger \& Ofek (1995) found that diversified firms sell at a discount compared to stand alone firms. They found a diversification discount in the range of 13 to 15 percent, for the period 1986 - 1991. Comment \& Jarrell (1995) and Liebesking \& Opler (1995) show that firms tended to become more focused, less diversified, in the 1970's and 1980's.

In general, the diversification discount is attributed to an inefficient internal capital market or other reasons such as the lack of business and managerial focus. If the internal capital market is efficient, it is expected to reduce the diversification discount. Consequently, if the internal capital market is inefficient, the diversification discount is expected to increase.

The firm's decision to track a business segment, rather than spinning-off that unit, suggests that the firm chose to preserve its internal capital market. However, preserving the internal capital market could be motivated by either a good performing internal capital market, or to preserve private benefits to managers. Spinning-off a business segment doesn't preserve the internal capital market, and also reduces private benefits in case they exist. Therefore, 
the decision to preserve or destroy the internal capital market would be beneficiary to shareholders if the benefit-cost analysis behind this decision were carried and based on the firm's performance enhancing criterion. For a two segment firm, for example, the decision to spinoff one of the segments will completely eliminate the diversification discount due to the internal capital markets and other factors. However, the decision to issue a tracking stock preserves the internal capital market and doesn't entirely eliminate the diversification discount. Therefore, the diversification discount is expected to be lower for tracking stock firms than spinoff firms.

The issuance of a tracking stock preserves the internal capital market whereas a spinoff destroys it. Therefore, tracking stock firms are expected to have a more active and efficient internal capital market than spinoff firms. As a consequence, other things being equal, we might expect firms issuing tracking stocks to have a lower diversification discount than spinoff firms.

The following section investigates whether a diversification discount, or diversification premium (excess value), characterizes the performance of the three different categories of firms included in the sample. The diversification discount (or premium) is defined as the percentage difference between the diversified firm value and the sum of the imputed values of its segments if they were operating as stand-alone firms.

The excess value is computed for the firms issuing a tracking stock, the matched sample of spinoff firms, and the matched sample of diversified firms. The excess value is computed, following Berger \& Ofek (1995), for the period prior to the firm's decision to restructure through a tracking stock or a spinoff.

For any given firm, each segment is matched to a portfolio of single segment firms that are in the same 2digit SIC code. The imputed value for each segment is calculated by multiplying a segment's accounting item (assets, sales, EBIT) by the ratio of total capital to the accounting item, for the median single segment firm. Total capital is defined as the book value of debt plus the market value of common equity. The imputed value of the firm is computed by summing the imputed value of all the segments of the firm. As a result, the excess value for each firm is calculated as the natural logarithm of the ratio of the firm's actual value to its imputed value. Table 3 reports the mean and median excess values for the tracking stock firms, the matched sample of spinoff firms, and the matched sample of diversified firms. The significance of the mean excess value is based on the t-test. As for the significance of the median values, it is based on the Wilcoxon signed-rank test. Furthermore, extreme excess values are eliminated. The excess values are said to be extreme when the firm's actual value is more than two times or less than half of the firm's imputed value.

Table 3: Diversification Discount (Premium)

\begin{tabular}{|l|l|l|l|c|}
\hline & & Tracking & Spinoffs & Diversified \\
\hline Assets Multiples & Mean & $0.10^{* * *}$ & $0.048^{*}$ & $0.092^{* * *}$ \\
\hline & Median & $0.20^{* * *}$ & 0.037 & $0.126^{* * *}$ \\
\hline Sales Multiples & Mean & 0.046 & $-0.195^{* *}$ & 0.034 \\
\hline & Median & 0.045 & -0.057 & -0.030 \\
\hline EBIT Multiples & Mean & -0.050 & $-0.383^{* * *}$ & $-0.264 * * *$ \\
\hline & Median & -0.087 & $-0.337 * * *$ & $-0.151^{* * *}$ \\
\hline
\end{tabular}

The asterisks $* * *, * *, *$ denote significance at the $1 \%, 5 \%$, and $10 \%$ level, respectively.

For tracking stock firms, the results show that the excess value is positive using asset multiples and sales multiples, whereas it is negative using EBIT multiples. However, the excess value is only significantly different from 0 , at the $1 \%$ level of significance, using asset multiples. The mean excess value, using asset multiples is $10 \%$, while the median is $20 \%$. For spinoff firms, only the mean excess value (4.8\%) using asset multiples is significant at the $10 \%$ significance level. Although the mean and median excess values for diversified firms are positive and significant at the $1 \%$ significance level, they are lower than those for tracking stock firms (but higher than spinoff firms).

Using sales multiples, the mean and median excess values for firms issuing a tracking stock are positive but not significant. The mean and median excess values for diversified firms are positive but lower than those for tracking stock firms, but also insignificant. However, the mean excess value for spinoffs is a negative 19.6\%, and it is significant at the 5\% significance level. Using EBIT multiples, the mean and median are always negative but they 
are insignificant for firms issuing tracking stocks. The diversification discount is negative and significant for both spinoffs and diversified firms. However, the results are more negative for spinoffs with a mean diversification discount of $-38.3 \%$ and a median of $-33.73 \%$.

In general, the results show that the excess value measures are not well behaved since there is too much variability in these measures for all three categories of firms. However, in all situations, the results show that tracking stock firms have the highest excess value (or the lowest diversification discount).

Moreover, the excess value measures for diversified firms are always higher than those for spinoff firms (which have the lowest excess values).

\section{EMPIRICAL FINDINGS ON THE EFFICIENCY OF INTERNAL CAPITAL MARKETS}

The model used to test the efficiency of the internal capital markets for all three categories of firms has the same spirit as the model used by Shin \& Stulz (1998). In particular, I investigate the dependence of segment investment, measured by gross capital expenditure, on the segment's as well as other segments' cash flows. As argued by Shin \& Stulz (1998), a similar reaction by segment's investment to an increase in segment's cash flow, and other segments' cash flows is an indication of an active and efficient internal capital market. As a matter of fact, Shin and Stulz (1998) findings of heavy reliance of segment investment on its own cash flow, was interpreted as a sign of inactive and inefficient internal capital markets in diversified firms.

This research will study how efficient the internal capital markets are in two special groups of diversified firms; namely, those firms who chose to spin-off business units and firm who opt for tracking business units as a mean of restructuring. A pair matching sample of diversified firms, who did not undergo restructuring, is included as a control group. If valuable internal capital markets are the driving force behind the choice of tracking stocks, and less valuable internal capital behind the choice of spinoffs, then one would expect more efficient internal capital markets in firms that track, rather than spin-off business units.

Allowing for fixed effects, this model studies how sensitive segment's investment to its own, as well as other segments' cash flows. Control variables include segment-to-firm sales ratio, segment investment opportunities proxied by Tobin "Q" firm.

The following is a summary of the symbols and variables used in the Model:

CAPX: Represents the segment investment measured by annual gross capital expenditure.

CFs: Segment's cash flow. It is defined as operating income or earnings before interest and tax, plus depreciation.

OCF: $\quad$ Represents the other segment's cash flow (i.e. $\mathrm{CF}_{\mathrm{f}}-\mathrm{CF}_{\mathrm{s}}$ )

A $\quad$ : $\quad$ Firm's identified assets.

$\mathbf{S}_{\mathrm{s}}: \quad$ Segment's sales.

$\mathbf{S}_{\mathrm{f}}$ : $\quad$ Firm's sales.

Tobin $\mathbf{Q}_{\mathbf{s}}$ : Segment's Tobin Q. A measure of the segment's investment opportunities.

The first regression equation is applied to all three groups of firms. The purpose is to estimate the relationship between the segment capital expenditure (investment) and the segment's own cash flow, the other segment's cash flows, all normalized by the firm's identified assets. The regression equation also utilizes some control variables such as the sales-to-firm ratio, and the segment's investment opportunities (Tobin Q). Two other interactive variables $\left(D_{1} \cdot C F_{S}, D_{2} \cdot C F_{S}\right)$ are included. $D_{1}$ is a binary variable that takes a value of "l" for spin-off firms and " 0 " otherwise. On the other hand, $\mathrm{D}_{2}$ is a binary variable that takes a value of " 1 " for diversified firms and "0" otherwise. The first interactive variable $\mathrm{D}_{1} \mathrm{CF}_{\mathrm{s}}, \mathrm{D}_{1}$ times $\mathrm{CF}_{\mathrm{s}}$, is supposed to investigate whether the dependence of segment capital expenditure, for spin-offs firms, shows more or less sensitivity to segment's own cash flow than the other two groups of firms. Similarly, the second interactive variable $\mathrm{D}_{2} \mathrm{CF}_{\mathrm{S}}, \mathrm{D}_{2}$ times $\mathrm{CF}_{\mathrm{s}}$, is supposed to investigate whether the dependence of segment capital expenditure, for diversified firms, shows more or less sensitivity to segment's own cash flow than the other two groups of firms. 
Table 4: Estimates for all Firms

\begin{tabular}{|l|c|c|}
\hline \multicolumn{1}{|c|}{ Model } & Coefficient Estimates & t- statistic \\
\hline Constant & -.003 & -1.63 \\
\hline CFs/A & .1245 & 7.00 \\
\hline OCF/A & .0278 & 3.01 \\
\hline Tobin $\mathbf{Q}_{\mathbf{s}}$ & .0022 & 2.36 \\
\hline $\mathbf{S}_{\mathbf{s}} / \mathbf{S}_{\mathbf{f}}$ & .0412 & 8.93 \\
\hline $\mathbf{D}_{\mathbf{1}} \cdot \mathbf{C F}_{\mathbf{s}}$ & .0527 & 1.95 \\
\hline $\mathbf{D}_{\mathbf{2}} \cdot \mathbf{C F}_{\mathbf{s}}$ & .0256 & .98 \\
\hline $\mathbf{R}-\mathbf{s q u a r e}$ & 0.21 & \\
\hline
\end{tabular}

Dependent Variable: CAPXs/A

The "efficiency" of internal capital markets is reached, as indicated by Shin \& Stulz (1998), when the following two conditions are met:

1- A dollar increase in the firm's cash flow, whether this increase comes from segment's cash flow or other segment's cash flow, should have the same impact on the segment's investment.

2- $\quad$ Segment's investment shouldn't be highly sensitive to segment's cash flow. Instead, the decision to invest more in a business unit should rely also on some other absolute and relative measures of performance. This might include, segment's investment opportunities, and sales ratio.

To that effect the introduction of interactive variables on both, spin-offs and diversified firms, is important. A positive sign on the coefficients of the interactive variables indicate more reliance of segment's investment on own cash flow for spin-offs and diversified firms, compared to their peer of tracking-stock firms. This could signal less efficient capital markets in both groups of firms relative to firms that track business unit.

Table (4) presents a summary of the results. Segment cash flow, other segments; cash flows, and segmentto-firm sales ratio, are all statistically significant at the 1 percent level of significance. Segment's Tobin Q and the interactive variable on spin-offs are both statistically significant at the 5 percent. All coefficients carry the predicted positive signs. That is, segment investment is positively related to its own and firm's cash flow. Segment's investment is also sensitive and directly related to the performance measures in absolute and relative terms. Only the interactive variable on diversified firms is not statistically significant. The positive signs of the interaction variables indicate more reliance on own segment cash flow for diversified and spin-off firms and more so for spin-offs since the coefficient is statistically significant. A \$1 increase in segment's cash flows has much more weight (6 folds) than a $\$ 1$ increase in other segments cash flows.

Although the results indicate that firms included in this sample, on average, pay attention to segments' performance measures, the low sensitivity of the segment's investment to other segments cash flows implies inactive internal capital markets. Clearly the "all firms" sample results don't support the presence of efficient internal capital markets.

The treatment of the first regression (Table 4) is able to distinguish, through the interactive variables, some significant differences between tracking-stocks firms and spin-off firms, concerning the segment's investment decisions. To be able to investigate more thoroughly differences in internal capital markets efficiency between the three groups of firms, I estimate three different regression equations, each represent one of the groups included in the "all firms" sample.

Except for the interactive variables, Regressions "2", “3”, and "4" utilizes the same explanatory variables included in the first regression (Table 4). Results in table (5), on tracking-stock firms, show that segment cash flow and performance-measure variables are all statistically significant at 1 percent. While other segment's cash flows is statistically significant at the 5 percent. More importantly, a \$1 increase in own cash flow now is approximately 3.5 folds the impact of a \$1 increase in other segment's cash flow. Though this result doesn't support the presence of perfectly efficient internal capital markets for tracking stocks, it signals a much more efficient and active performance for such firms compared to "all-firms" sample. The coefficient on segment cash flow is lower for tracking-stocks sample compared to that in regression one which means lower reliance on own-cash flow, the 
coefficients on segment Tobin Q and segment-to-firm sales are higher for tracking-stock firms compared to "allfirms", and this implies that firms that opt for tracking business units pay more attention to segment's absolute and relative measures of performance. These results show definite improvement, not necessarily perfect improvement, in the working of the internal capital markets for this group of tracking-stock firms.

Table 5: Estimates for Tracking-Stock Firms, Diversified firms, and Spin-off firms.

\begin{tabular}{|c|c|c|c|c|c|c|}
\hline \multirow[t]{2}{*}{ Model } & \multicolumn{2}{|c|}{$\begin{array}{l}\text { Tracking-Stock } \\
\text { (Regression 2) }\end{array}$} & \multicolumn{2}{|c|}{$\begin{array}{c}\text { Diversified } \\
\text { (Regression 3) }\end{array}$} & \multicolumn{2}{|c|}{$\begin{array}{c}\text { Spin-off } \\
(\text { Regression 4) }\end{array}$} \\
\hline & Coefficient Estimates & t-value & Coefficient Estimates & t-value & Coefficient Estimates & t-value \\
\hline Constant & -.0080021 & -1.90 & -.0044629 & -1.37 & -.001446 & -.51 \\
\hline CFs/A & .1134931 & 4.98 & .1490709 & 6.33 & .1852722 & 8.00 \\
\hline OCF/A $f$ & .0318786 & 1.96 & .0106367 & .72 & .0170771 & 1.13 \\
\hline $\mathbf{S}_{\mathrm{s}} / \mathbf{S}_{\mathrm{f}}$ & .0497794 & 5.51 & .0466389 & 5.87 & .0348942 & 5.49 \\
\hline Tobin Qs & .0046496 & 2.53 & .0030734 & 1.88 & .0022827 & 1.98 \\
\hline R-square & \multicolumn{2}{|l|}{0.2053} & \multicolumn{2}{|l|}{0.1959} & \multicolumn{2}{|l|}{0.3440} \\
\hline
\end{tabular}

Dependent Variable: CAPX $_{\mathrm{S}} / \mathrm{A}_{\mathrm{f}}$

To shed more light on the differences in performance of internal capital markets among the three groups of conglomerate firms, two more regression models are used: One for the diversified firms (regression 3) and one for the firms that chose to spin-off business units (regression 4).

Also, Table (5) shows the results for regressions "3" and "4". Only segment's cash flow and segment-tofirm sales ratio are statistically significant at the 1 percent. Segment Tobin "Q" is statistically significant at the 5 percent for Spin-off firms and statistically significant at the 6 percent for diversified firms. While other segment's cash flows is not statistically significant for both groups. The impact of $\$ 1$ increase in own cash flow has much greater influence on segment's investment than other segment's cash flows (almost 15 folds for both groups).

Compared to tracking-stock firms, segment investment decision in diversified firms rely more on its own cash flow and much less on other segment's cash flow. The coefficients on performance-measures are also lower for diversified firms. All of the above indicates that diversified firms don't enjoy an "efficient" internal capital markets compared to the sample of firms that track business units.

Results for spin-off firms indicate that, for this group of firms, capital expenditure by segments relies heavily on its own cash flow relative to the other two samples of firms. Sales ratio and segment's Tobin Q are both statistically significant at the 1 percent and 5 percent respectively. However, the coefficients on both variables are lower than the cases of diversified and tracking stock firms.

The statistically significant coefficient on own cash flow is higher for spin-offs than diversified and tracking -stock firms, which is consistent with the results revealed by the interaction variables used in "all-firms" sample. Such results shouldn't be surprising for firms who opt for spinning-off business units since there doesn't seem to be an advantage from keeping the internal capital markets. Segments of spin-off firms seem to work as independent entities with no attention to relative performance measures, and the consolidated firm's cash flow.

\section{CONCLUSION}

Previous research emphasized the important role that the internal capital market plays in value-creation or value-deterioration of conglomerate firms. The positive market reaction for announcements on spin-offs, as well as, tracking stocks, has been accredited to more focused business that "destroys" the internal capital market for the first form of restructuring, and to the preservation of efficient internal capital markets for the later form of restructuring. This paper used a pair-matching procedure to construct three samples of conglomerate firms. Namely, trackingstock firms and spin-off firms who opt for restructuring, as well as diversified firms who didn't.

Compared to diversified and spin-off firms, the results indicate that firms who opt for tracking units had the highest diversification "premium" by the time of restructuring . On the other hand, diversification discount was most significant for firms who opt for spin-offs by the time of restructuring announcements. To the extent that firm 
diversification premium (discount) is regarded as a market reward (penalty) for the performance of internal capital markets, the findings are in conformity with the hypothesis that tracking-stock firms enjoyed better performing internal capital markets than both diversified and spin-off firms.

Empirical findings showed that the segment's investment, in tracking firms, is sensitive to the segment's cash flow as well as to other segments cash flow. Moreover, the internal capital market pays attention to absolute and relative performance measures of its segments. That is, company's resources are channeled from poor performing to better performing segments. Meanwhile, both diversified and spin-off firms had less efficient internal capital markets as compared to tracking-stock firms. In particular, the segment's investment, in both groups of firms, is not sensitive to the firm's cash flow, and less sensitive to relative measures of performance as compared to tracking-stock firms. The high reliance of segment investment on its own cash flow for spin-offs suggests that the segments behave independently, and this is a sign of inactive and inefficient internal capital markets. The results support the argument that better internal capital markets could be behind the choice of tracking business units instead of spinning-off those units and vice-versa.

\section{AUTHOR INFORMATION}

Dr. Anwar Boumosleh holds a Ph.D. in Finance from the University of Alabama. He has been teaching MBA corporate Finance and Investments since joining LAU in 2005. Dr. Boumosleh also taught at the University of Central Florida. His research interest is in corporate finance; specifically, corporate governance and CEO and director compensation. Dr. Boumosleh is also a CFA and has worked in the Lebanese banking industry. E-mail: anwar.boumosleh@lau.edu.lb

Dr. Abdallah Dah is a Full Professor of Economics at the Lebanese American University, Beirut, Lebanon. He earned a Ph.D. in Economics from the University of Colorado Boulder in 1988. His research areas include oil forecasting, energy consumption, price theory, tax incidence, discrimination theory. Dr. Dah has published in journals such as Journal of Applied Energy, Journal of Energy and Development and International Journal of Business Research. E-mail: aadah@lau.edu.lb (Corresponding author)

Dr. Mustafa Dah is an assistant professor of Finance at the Lebanese American University. He earned his Ph.D. in Finance from the University of Central Florida. His research interest is in the area of Corporate Finance. E-mail: mustafa.dah@lau.edu.lb

\section{REFERENCES}

1. Aggarwal, R. and Samwick, A. (2003), Why do managers diversify their firms? Agency reconsidered, Journal of Finance 58, 71-118.

2. Berger, P. G., and Ofek, E. (1995), Diversification's effect on firm value, Journal of Financial Economics 37, 39-65.

3. Billett, M. T., and Mauer, D. C. (2000), "Diversification and the Value of Internal Capital Markets: The case of Tracking Stock," Journal of Banking and Finance, 24(9), pp. 1457-1490.

4. Campa, J. M., and Kedia, S. (2002). "Explaining the Diversification Discount," Journal of Finance, American Finance Association, vol. 57(4), pages 1731-1762, 08.

5. Chemmanur, T. and Yan, A. (2004) A theory of corporate spin-offs. Journal of Financial Economics 72, 259-290.

6. Chemmanur, T. and Paeglis, I. (2001). Why Issue Tracking Stock? Insights From A Comparison With Spin-Offs And Carve-Outs. Journal of Applied Corporate Finance, Morgan Stanley, vol. 14(2), 102-114.

7. Comment, R. and. Jarrell, G.A (1995), “Corporate Focus and Stock Returns," Journal of Financial Economics 37, 67-87.

8. D'Mello. R, Krishnaswami, S. and Larkin, P.J. (2008). Determinants of corporate cash holdings: evidence from spin-offs. Journal of Banking and Finance 32, 1209-1220.

9. Danielova, A. N (2008). "Tracking stock or spin-off? Determinants of choice." Financial Management Association.

10. Denis, David J., Diane K. Denis, and Sarin A. (1997). "Agency Problems, Equity Ownership and Corporate 
Diversification." The Journal of Finance 52 , 135-160.

11. D'Souza, J. and Jacob J. (2000). "Why Firms Issue Targeted Stock." Journal of Financial Economics 56 (3):459-83.

12. Elder, J. and P. Westra, (2000), "The Reaction of Security Prices to Tracking Stock Announcements," Journal of Economics and Finance 24, 36-55.

13. Graham J., M. Lemmon and J. Wolf (2002),"Does corporate diversification destroy value?". The Journal of Finance, 57, pp. 695-720.

14. Jensen, M. and Meckling W. (1976), Theory of the firm: managerial behavior, agency costs, and ownership structure, Journal of Financial Economics 3, 305-360.

15. Liebeskind, J. and T. Opler, 1995, "The Causes of Corporate Refocusing: Evidence from the 1980s," University of Southern California, Working Paper.

16. Morck R., Shleifer A. and Vishny R.W (1990), "Do Managerial Objectives Drive Bad Acquisitions" The Journal of Finance, Vol. 45, No. 1, March

17. Myers, S. and N. Majluf, 1984 "Corporate Financing and Investment Decisions when Firms have Information that Investors Do Not Have", Journal of Financial Economics, 13, No. 2, pp. 187-221.

18. Patro, S. (2008). The evolution of ownership structure of corporate spin-offs. Journal of Corporate Finance 14, 596-613.

19. Rajan R., H. Servaes and L. Zingales, The cost of diversity: The diversification discount and inefficient investment. The Journal of Finance, 55 (2000), pp. 35-80.

20. Scharfstein, D. and Stein, J. (2000), The dark side of internal capital markets: Divisional rent-seeking and inefficient investment, Journal of Finance 55, 2537-2564.

21. Shin, H. and Stulz R. (1998), Is the internal capital market efficient? Quarterly Journal of Economics 108, 531-552.

22. Stein, J. (1997), Internal capital markets and the competition for corporate resources, Journal of Finance $52,111-133$.

23. Storm, S., 1994. It's Called Targeted Stock; Shun It, Some Experts Say. New York Times, July 12.

24. Stulz, R. M., (1990), Managerial discretion and optimal financing policies, Journal of Financial Economics 26, 3-27.

25. Veld, C. and Veld- Merkoulova, Y.V. (2009). Value creation through spin-offs: A review of the empirical evidence. International Journal of Management Reviews, Vol. 11, Issue 4, pp. 407-420.

26. Veld, C. and Veld-Merkoulova, Y.V. ( 2004). Do spin-offs really create value? The European case, Journal of Banking and Finance 28, 1111-1135.

27. Villalonga B., (2004), Diversification discount or premium? New evidence from the Business information tracking series, Journal of Finance 59, 479-506.

28. Weston, J. F., (1970), The nature and significance of conglomerate firms, St. John's Law Review 44, 66-80.

29. Yermack, D. 2006. Flights of Fancy: Corporate Jets, CEO Perquisites, and Inferior Shareholder Returns. Journal of Financial Economics 80, 211-242. 